\title{
O CONTEXTO, O SOCIAL E A QUESTÃO DO SUJEITO LÍRICO EM GLAUCO MATTOSO
}

\author{
Ricardo Alves dos Santos ${ }^{1}$
}

\begin{abstract}
Resumo: Nesta reflexão, propomos uma avaliação do contexto de produção artística do poeta Glauco Mattoso alinhada à constituição do sujeito lírico edificado no projeto dele. Para tanto, à princípio, discorremos sobre o panorama crítico acerca da literatura contemporânea, buscando refletir sobre algumas direções críticas e teóricas sobre as produções líricas da atualidade. Além disso, buscamos a ressonância do que se considera "literatura marginal" na poesia de Glauco Mattoso, na qual observamos um elo entre vida e obra na tessitura artística do autor. Por fim, analisamos dois sonetos de Glauco Mattoso: "Formal" e "Convicto", na tentativa de perceber o quanto o trabalho realizado pelo poeta se revela como uma poesia de resistência que carrega em seu bojo criativo um deslocamento dos princípios tradicionais e conservadores acerca da arte e da vida.
\end{abstract}

Palavras-Chave: Contemporaneidade literária. "Poesia marginal”. Glauco Mattoso.

\section{THE CONTEXT, THE SOCIAL AND THE QUESTION OF THE LYRICAL SUBJECT IN GLAUCO MATTOSO}

\begin{abstract}
In this reflection, we propose an appraisal of the artistic production context of the poet Glauco Mattoso accord to the constituition of the lyric subject edified in his project. For so, at first, we will disclose the critical panorama about contemporary literature, seeking to reflect on some critical and theoretical directions about the lyrical productions of current. Besides, we seek the resonance of what is considered 'marginal literature' in Glauco Mattoso' s poetry, in which we observe a link between life and work in the artistic thesis of the author. Finally, we analyze two sonnets by Glauco Mattoso: "Formal" and "Convicto", in an attempt to understand how the work done by the poet reveals itself as a poetry of resistance that carries in its creative center a displacement of the traditional and conservative principles about of art and life.
\end{abstract}

Keywords: Literary Contemporary. 'Marginal literature'. Glauco Mattoso.

\footnotetext{
${ }^{1}$ Doutor em Estudos Literários pela Universidade Federal de Uberlândia. Professor de Linguagens em escolas públicas e particulares. E-mail: ricardo.ia.alves@gmail.com.
} 
Crer que a poesia, de uma maneira ou de outra, esboça um olhar direcionado para a vida, parece uma premissa já consolidada nos estudos literários. As implicações dessa constatação permeiam a crítica contemporânea, que se encontra inserida nas tensões causadas pelo desconforto da pluralidade decantada em solos democráticos. A emergência de sujeitos que acionam os caminhos artísticos para se pronunciar e reivindicar um lugar de fala promove, na atualidade, uma necessária cautela quanto ao tratamento dado ao discurso da crítica presente.

A "heterogeneidade da cena literária" inviabiliza uma postura radical acerca do produto literário. Célia Pedrosa (2015), em "Poesia e crítica de poesia hoje: heterogeneidade, crise, expansão", chama-nos a atenção para o caráter "aberto" e lacunar incitado por aquilo que denominamos como contemporâneo. Não há maneira unívoca para demarcar, assinalar ou agrupar autores e obras, visto que o exercício poético e sua inscrição no tempo encontram-se distantes de uma possível estabilidade de formas e de expressões artísticas.

Pedrosa sinaliza que a questão do contemporâneo sublinha a problemática ideia de "presente", o qual se caracteriza por "forças contrariamente históricas e anti-históricas". Esta contradição, inerente ao presente, abre parênteses para deslocarmos as concepções ditas tradicionais nas artes e em outras esferas sociais e culturais. Reconhecer o caráter histórico e o passado como constituintes do presente não pode apagar a necessidade de valorizar o tom pluralista que ronda o processo de modernidade da arte, uma vez que, desde os românticos, o literário se enche de ironia para tratar de temas que exalam o odor emanado das "necessárias" formas para se consolidar o progresso, a ciência, o enriquecimento e, consequentemente, a higienização dos modos e costumes avessos à sociedade burguesa e judaico-cristã consolidada nestes tempos.

O diverso não está de acordo com as estruturas de poder empreendidas no seio do capital. Segundo Pedrosa (2010), as "forças modernas", assinaladas pelo mercado liberal, os avanços tecnológicos e suas formas de "produção, reprodução e circulação das práticas e discursos, associados à crise deflagrada pelas experiências de guerra quanto à demanda por diferentes modos de legitimação individual e coletiva" (PEDROSA, 2010, p. 
169) traçam paradigmas que enfatizam e desestabilizam o sistema crítico e literário. O tripé autor, obra e leitor arranja-se diversamente hoje, seja pela diversidade sexual e social do público que consome e produz a obra ou pela variedade de suportes de veiculação dela, haja vista os vários escritores negros, LGBTQI+ ${ }^{2}$, do sexo feminino, que diariamente iniciam suas formulações literárias através dos recursos propiciados pela internet e pelas políticas afirmativas. Isso não significa dizer que o diverso não se encontra representado em obras de outros tempos, mas agora o representado ganha a assinatura de sujeitos que desejam se autorrepresentar, construindo, a partir de uma postura artística reivindicatória, um diálogo crítico e irônico a respeito das tramas e dos engenhos articulados hegemonicamente pelo discurso burguês operante em todas as esferas da sociedade.

Desse modo, legitimar os corpos e os sujeitos que, ao longo da história, foram apagados por uma promoção deliberada para consolidar um patriarcado soa como prerrogativa incessante na atualidade, porquanto a sociedade burguesa articulou-se científica ou religiosamente no intuito de construir uma estrutura homogeneizadora dos seres, ou seja, a condição do homossexual, do negro, da mulher, do pobre, do não cristão e de diversas outras configurações existenciais é marginalizada e passa a ter um tratamento excludente no que tange às questões da dignidade humana. Interessa-nos, nesta reflexão, situar a poética de Glauco Mattoso como discurso homoerótico e promovedor de deslocamentos estético-literários, reivindicando, no artístico, o que na realidade objetiva não encontram: lugar de fala.

\footnotetext{
2 Segundo Glauco Ferreira (2012), "A sigla "LGBT" é resultante de variadas discussões realizadas no interior do movimento social reconhecido anteriormente no Brasil como "Movimento Homossexual". Ao longo de suas histórias, no Brasil e no mundo, e a partir das diferenciações entre os diversos segmentos identitários articulados em seus interiores, estes movimentos sociais começaram a ser referidos como "LGBT", significando o agrupamento dos segmentos de Lésbicas, Gays, Bissexuais, Travestis e Transgêneros ali reunidos (sigla na qual muitas vezes são adicionadas três letras " $\mathrm{T}$ " ao final, para distinguir cada um dos três termos e identidades "trans" representadas). Mais recentemente, em âmbito internacional principalmente, a letra " $Q$ " (representando os segmentos que se autodefinem Queers) e a letra "I" (representando os segmentos denominados Intersexo, anteriormente conhecidos como hermafroditas) foram adicionados à sigla "LGBT", resultando em "LGBTQI"”" (FERREIRA, 2012, p. 71). Há, também, o emprego da sigla "LGBTQI+", que agrega o símbolo "+" para designar outras identidades de gênero não contempladas em "LGBTQI".
} 
Assistimos a mudanças consideráveis das práticas sexuais nos últimos 50 anos: "Cada vez mais os indivíduos são encorajados a escolher livremente como viver a sua sexualidade e o tipo de relação ou família que desejam construir" (POMBO, 2017, p. 389). As novas configurações familiares e sexuais levam-nos a constatar arranjos variados que nos permitem levantar questionamentos sobre o modelo heterossexual vigente, o qual, a partir do binarismo sexual (homem e mulher) e da consequente naturalização dele, acaba excluindo os prazeres e desejos avessos ao discurso heteronormativo que rege os corpos sexuados. A heteronorma ou heteronormatividade é o padrão sexual dos povos ocidentais, determinado na/pela cultura, e que exerce o poder de reiterar como normal apenas as relações sexuais entre pessoas de sexos diferentes. A dominação heterossexual, segundo Monique Wittig (2006), tem suas bases alicerçadas em três pilares diferenciadores dos sexos: a constituição biológica, hormonal, genética, a divisão para o trabalho e a ideia de uma natureza inata dos corpos. Dessa maneira, a solidificação das distinções sexuais acaba por estabelecer uma hierarquização dos sexos e, consequentemente, cria-se uma estrutura promovedora de diversas formas de opressão e exclusão a partir de estratégias consolidadoras da heterossexualidade. Qualquer configuração sexual que escapa do binarismo (homem/ mulher) sofre alguma forma de discriminação e preconceito, porque “a sociedade heterossexual não é a sociedade que oprime somente as lésbicas e os gays, oprime a muitos outros/diferentes, oprime a todas as mulheres e a numerosas categorias de homens, a todos os que estão na situação de dominados"3 (WITTIG, 2006, p. 53, tradução nossa). Judith Butler (2012, p. 3839) faz as seguintes considerações acerca da "heterossexualização":

A heterossexualização do desejo requer e institui a produção de oposições discriminadas e assimétricas entre "feminino" e "masculino", em que estes são compreendidos como atributos expressivos de "machos" e "fêmeas". A matriz cultural por intermédio da qual a identidade de gênero se torna inteligível exige que certos

\footnotetext{
${ }^{3}$ No original: "la sociedad heterosexual no es la sociedad que oprime solamente a las lesbianas y a los gays, oprime a muchos otros/diferentes, oprime a todas las mujeres y a numerosas categorias de hombres, a todos los que están en la situación de dominados".
} 
tipos de "identidade" não possam existir - isto é, aquele em que o gênero não decorre do sexo e aquelas em que as práticas do desejo não "decorrem" nem do "sexo" nem do "gênero".

A filósofa estadunidense, conhecida por colaborar nas formulações da teoria $q^{4} e e r^{4}$, em suas palavras, confronta-nos diretamente para o poder que a cultura exerce sobre os corpos sexuados. Para a pensadora, a inteligibilidade dos gêneros se dá por meio da "coerência" e da "continuidade" entre "sexo, gênero, prática sexual e desejo", e a regulação acerca da sexualidade humana está amarrada às estratégias legais para evitar e proibir qualquer descontinuidade e incoerência das práticas sexuais. Assim, o indivíduo com sexo biológico feminino não poderia ter desejo por um ser humano com a mesma correspondência genital, mostrando, nesse sentido, uma subversão desnaturalizada da sexualidade humana. "A heterossexualização do desejo" é a única via legitimada pela cultura para a satisfação dos desejos sexuais, e o viés normativo dessa empreitada reguladora reproduz-se de maneira ordenada e organizada sobre os corpos, o que "suprime a multiplicidade subversiva de uma sexualidade que rompe as hegemonias heterossexuais, reprodutivas e médico-jurídicas" (BUTLER, 2012, p. 41). Aquilo que foge, portanto, à heteronorma e aos produtos que geram a máquina desenfreada do progresso é anulado e excluído.

Mergulhado neste contexto heterogêneo e plural, Glauco Mattoso exemplifica bem as novas exigências e prerrogativas que imperam na contemporaneidade, tão enriquecida pela diversidade de vozes dissonantes dos imobilizadores padrões acerca da arte e da vida. Esse poeta comunga de uma vida literária imersa na exclusão social, seja por ser homossexual, seja por ser cego. A poesia dele revela condições existenciais que nutrirão seus

\footnotetext{
4 "A teoria queer é um conjunto de estudos e enunciados, de vários autores, sobre a construção social da sexualidade e do gênero, com forte influência de Michel Foucault. A teoria queer faz uma crítica radical das identidades sexuais tidas como essências imutáveis. Devido à sua postura anti-identitária e antiuniversalista, muitas vezes ela se posiciona de maneira divergente em relação a alguns teóricos gays e feministas que reivindicam igualdade de direitos e maior inclusão social da homossexualidade. A importância do uso do termo queer está na reapropriação que se fez dele. Inicialmente utilizado de modo pejorativo e como insulto a homossexuais, queer foi positivado e ressignificado por seus teóricos, passando a ser usado para descrever práticas subversivas, que se colocam contra as normas sexuais dominantes, sobretudo a da heterossexualidade" (POMBO, 2017, p. 389).
} 
exercícios reivindicatórios, construídos com base naquilo que a crítica consolidou como "cultura de resistência".

O poeta supracitado iniciou sua produção nos anos de 1970. Parte da literatura que se vê neste período recebe a denominação de "poesia marginal" e, consequentemente, seus autores são designados como poetas marginais. O rótulo que se apresenta, desde então, destaca uma problematização semântica para a análise estético-literária destes escritores. Primeiramente, a palavra "marginal" pode apresentar uma acepção substantiva, relacionandose a um indivíduo que pratica atos ilícitos e, assim, viveria às margens do sistema dominante; este sentido de ordem corriqueira acaba por estabelecer o conflito de sentido que a poesia da década de 1970 carrega em seu bojo enunciativo, uma vez que o público, de maneira simplista, rotulava o fenômeno literário emergente como falacioso, em razão de seus escritores não pertencerem a um estrato social marginalizado. A literatura "marginal", portanto, descaracterizava-se do valor político e de resistência designado por essa acepção e, de certa forma, o caráter reivindicatório dos versos se perdia, tornando-se insuficiente para redimensionar as necessidades culturais e artísticas que o contexto político incitava. Entretanto, se deslocarmos o termo para uma função adjetiva, podemos identificar a ressonância de outras atribuições estético-literárias que direcionam a produção artística deste período.

A literatura dita "marginal" se consolidou a partir de uma mudança no endereçamento do texto literário, ampliando sua comunicabilidade por meio de uma linguagem sem rebuscamentos linguísticos e estilísticos ${ }^{5}$, o que permitia dialogar com um público menos conservador e mais diverso. A "facilidade" de leitura e interpretação dos textos marginais viabilizou uma sobreposição do discurso em detrimento do trabalho estético e esta característica da literatura "marginal" desqualifica a produção artística do período, sinalizando um empobrecimento do fator literário e estético. Por

\footnotetext{
${ }^{5}$ Apesar de esta postura quanto à linguagem da literatura marginal ser bastante difundida, cabe destacar que a poesia deste período não negligenciava a forma literária, pelo contrário, percebe-se que há um trabalho adestrado do poeta, dado que este é dotado de conhecimento formal acerca da linguagem literária, mas precisa adequar conteúdos diversos a uma sintaxe das massas sociais.
} 
outro lado, como sinaliza Heloísa Buarque de Hollanda (1998), os poetas "marginais" reencontraram "o elo entre poesia e vida", promovendo uma “desierarquização do espaço nobre da poesia”, além de deixarem de lado o permanente em prol de uma literatura investigativa e jovem, fruto de um contexto histórico ditatorial e militar que exigiu dos artistas da época formas diferenciadas para a circulação das obras artísticas, longe dos entraves engendrados pela política editorial de então.

O cenário cultural e artístico brasileiro, pré e pós 1964, era controlado pela esquerda intelectual, que conduzia o fazer poético a partir dos debates políticos, como bem pontuado por Hollanda (2004). O engajamento político dos artistas torna-se não só uma necessidade, mas uma essência para confrontar a ineficiência do Estado frente às "pressões de uma "nova modernidade" colocadas pelo capitalismo monopolista internacional" (HOLLANDA, 2004, p. 20). Nos primeiros anos do Golpe Militar, a classe artística esquerdista ainda detinha uma relativa hegemonia da cena cultural, entretanto, o alcance dos ideários revolucionários não atinge a massa popular, restringindo-se "a um público já "convertido" de intelectuais e estudantes da classe média" (HOLLANDA, 2004, p. 34).

O literato dessa época, ao propor uma parceria com o público, dar voz aos marginalizados, "propõe ao povo que o aceite como companheiro, oferece-se para estar ao seu lado" (HOLLANDA, 2004, p. 27). No entanto, esta parceria de unir literatura e massa social acaba por sucumbir; o Golpe Militar retira do projeto artístico revolucionário o endereçamento original, as classes populares são retiradas do circuito artístico.

O fracasso das aspirações literárias elevadas pelos escritores populistas ${ }^{6}$ acaba por estabelecer uma nova configuração do sistema cultural brasileiro. Com o acirramento e a rigidez da censura, a maneira encontrada pelos artistas para fazerem circular suas obras deu-se por vias "marginais". Resistir é o verbo que conduz as ações dos envolvidos no contexto tomado pelo autoritarismo e pela falta de liberdade. "O círculo fechado e viciado em

\footnotetext{
${ }^{6}$ Este termo é empregado no sentido usado por Heloísa Buarque de Hollanda (2004) para definir os escritores que, de maneira ingênua ou não, colocaram seus exercícios literários em sintonia com os anseios das camadas mais populares da sociedade brasileira da década de 1960.
} 
que a classe média informada juntava-se para falar do 'povo' não produzia mais efeito" (HOLLANDA, 2004, p. 71).

Esses apontamentos acerca da produção literária dos primeiros anos da Ditadura Militar brasileira servem para elucidar o perfil artístico empreendido nos anos 1970, o qual, segundo Hollanda, encontra-se indissociável das prerrogativas impostas pela censura. "Ou seja, a impossibilidade de mobilização e debate político aberto transfere para as manifestações culturais o lugar privilegiado da resistência" (HOLLANDA, 2004, p. 104). O povo, que está impedido de proferir suas reivindicações, ganha um porta-voz quixotescamente avesso às chancelas tradicionais, sejam as de ordem estatal ou as oriundas da especulação empresarial, ambas sustentadas pelo que se consagrou como "milagre econômico".

Rompendo decididamente com o sistema de editoração e de circulação das produções artísticas, alguns escritores tomaram o controle de todo o processo de criação, divulgação e distribuição de suas criações. A literatura da época emerge da quebra com o sistema editorial e de um claro alinhamento entre vida e obra, buscando "mudança nas próprias práticas culturais, nos modos de conceber a cultura fora de parâmetros sérios e eruditos" (OLIVEIRA, 2011, p. 31).

Da visão substantiva à adjetiva, notamos que o "termo marginal" carrega uma acepção ambígua desde a sua origem e

oscilou numa gama inesgotável de sentidos: marginais da vida política do país, marginais do mercado editorial, e, sobretudo, marginais do cânone literário. Foi uma poesia que surgiu com perfil despretensioso e aparentemente superficial mas que colocava em pauta uma questão tão grave quanto relevante: o ethos de uma geração traumatizada pelo cerceamento de suas possibilidades de expressão pelo crivo violento da censura e da repressão militar. Em cada poema-piada, em cada improviso, em cada rima quebrada, além das marcas de estilo da poesia marginal, pode-se entrever uma aguda sensibilidade para registrar - com maior ou menor lucidez, com maior ou menor destreza literária - o dia-a-dia do momento político em que viviam os poetas da chamada geração AI5 (HOLLANDA, 2018). 
A superficialidade, apontada por Hollanda, associa-se, basicamente, à postura de muitos críticos em considerar o desbunde dos poetas marginais um projeto sem tratamento estético, acepção ingênua se observarmos a multiplicidade de formas literárias desenvolvidas neste período, haja vista os poemas realizados por Glauco Mattoso, que dialogam incessantemente com a tradição através do uso de sonetos, glosas e trovas rigorosamente metrificados e ritmados. Esta posição crítica relaciona-se à confluência de fatores artísticos desencadeados pelo desconforto do discurso acadêmico mediante o fenômeno literário posterior ao Movimento da Poesia Concreta e seu experimentalismo linguístico e ao Tropicalismo, que decantava uma abordagem popular ${ }^{7}$. Os textos da década de 1970 não podem ser avaliados meramente pelo "descuido formal" que apresentam. A postura dos poetas "marginais" rompe com o sistema literário vigente, "faz-se clara a recusa tanto da literatura classicizante quanto das correntes experimentais de vanguarda que, ortodoxamente, se impuseram de forma controladora e repressiva no nosso panorama literário" (HOLLANDA, 1998, p. 10-11). Notamos, ainda, um nítido "recuo estratégico" que esses poetas estabeleceram com a coloquialidade poética dos autores dos primeiros anos do modernismo de 1922, em que a tônica coloquial ganha status "de inovação e ruptura com o discurso nobre acadêmico" (HOLLANDA, 1998, p. 11). Dessa maneira, a literatura "marginal" rompe com a concepção de uma poesia hermética nos moldes de João Cabral de Melo Neto e, também, dos experimentos verbovocovisuais ${ }^{8}$ da poesia concreta. Vale acrescentar que o aspecto coloquial encontrado nos poemas deste período difere da condução dada pelos poetas do primeiro tempo modernista, já que as realizações marginais têm um teor mais ambíguo e uma crítica alegórica "mais circunstancial e independente de comprometimentos com um programa preestabelecido" (HOLLANDA, 1998, p. $11)$.

\footnotetext{
${ }^{7}$ Esta afirmação é ratificada por Heloísa Buarque de Hollanda (2004, p. 42).

${ }^{8}$ Este neologismo foi criado por James Joyce e empregado por Haroldo de Campos em Teoria da poesia concreta (2006) para designar o trabalho poético dos concretistas, no qual o poema seria concebido a partir da integração de três elementos: o verbal, o vocal e o visual.
} 
Nesse contexto da literatura dita “marginal”, Pedro José Ferreira da Silva, paulistano, nascido em 1951, conhecido pelo seu pseudônimo Glauco Mattoso, cuja assinatura aparece pela primeira vez no poema "Kaleidoscópio", publicado em 1974, inicia sua produção artística. O trocadilho do nome deriva de uma doença, o glaucoma, que acabou por cegar o poeta ainda nos anos de 1990, além de fazer clara referência ao poeta barroco Gregório de Matos, reconhecido pelos seus poemas satíricos proferidos à sociedade baiana do século XVII. Ao longo de sua carreira de eclética filiação às formas literárias, e em sintonia com a variedade de funções que exerce/exerceu - ensaísta, sonetista, editor, produtor, tradutor, ex-funcionário público do Banco do Brasil -, Glauco Mattoso dirige seu olhar fescenino para a vida. O adjetivo fescenino traduz-se em uma atitude caleidoscópica em que a unidade não é o que o poeta percorre, mas, sim, sugere, como aponta Susana Souto Silva em sua tese O caleidoscópio Glauco Mattoso (2008). Trata-se de um exercício artístico fragmentado e, ao mesmo tempo peculiar, à medida que lança seu olhar para a realidade que o circunscreve, na tentativa de, contraditoriamente, fazer-se visto e se ver no espetáculo daqueles que se sentem injustiçados, como observado nas seguintes palavras do poeta, retiradas de uma entrevista de 2011:

A cegueira, a homossexualidade e o fetichismo podem ser comparados a uma série de situações de inferiorização, exclusão ou repressão. Isso me coloca, alegoricamente, na posição de qualquer pessoa oprimida, em qualquer parte do mundo, seja um cego ou um perseguido político. Então, se minha condição serve de metáfora, estou exercendo a maior função que um escritor pode ter: identificar-se com seu público (MATTOSO, 2011).

Chama-nos a atenção, na fala de Glauco Mattoso, o caráter alegórico que o poeta atribui a si mesmo e à sua poesia. Metamorfoseando-se em várias posições sociais que reivindicam, democraticamente, acolhimento e respeito, a poesia de Mattoso torna-se instrumento para deslocar, refletir e ressignificar a realidade de muitos que anseiam por um lugar de fala.

Em "Palestra sobre lírica e sociedade", Theodor Adorno tensiona exatamente a rigidez com que a crítica tradicional estrutura a categorização 
do texto literário, visto que, para esta, a poesia lírica tem sua "essência precisamente em não reconhecer o poder de socialização" (ADORNO, 2003, p. 66), e seu caráter narcísico poderia nos direcionar a uma leitura de mera “demonstração de teses sociológicas". Para evitar uma interpretação unilateral da lírica, Adorno (2003, p. 66) atenta-nos:

o teor [Gehalt] de um poema não é mera expressão de emoções e experiências individuais. Pelo contrário, estas só se tornam artísticas quando, justamente em virtude de suas especificações que adquirem ao ganhar forma estética, conquistam sua participação no universal.

Dessa maneira, a qualidade do social depreendido da lírica se dá pelo tratamento estético realizado, e a partir dele o que era de cunho particular e íntimo pode antecipar um modo não distorcido e não submisso acerca do mundo objetivo. A esperança de quem lida com a lírica é, neste processo de “individuação", extrair o universal, mesmo se arriscando a uma contingência existencial meramente isolada, como bem sinalizado por Adorno. Cabe destacar, neste momento, que "o pensar sobre a obra de arte está autorizado e comprometido a perguntar concretamente pelo teor social, a não se satisfazer com o vago sentimento de algo universal e abrangente" (ADORNO, 2003, p. $67)$.

A questão do "universal" assinalado por Adorno faz críticas ao idealismo alemão, principalmente, às postulações metafísicas de Hegel sobre a poesia lírica. Hegel vê a poesia como uma manifestação plena e total da subjetividade lírica, e esta se constrói a partir das imagens evidenciadas em um poema. Desse modo, a sobreposição das metáforas e a consequente disposição imagética sustentariam a particularidade do sujeito enunciativo. Delineia-se, portanto, uma visão idealista de romper com as contradições e oposições concebidas pela relação entre homem e mundo, pois a integração dos dois universos cindiria qualquer possibilidade de rompimento entre o interior e o exterior. A subjetividade lírica, assim, tem uma unidade que se edifica pelas imagens, fechando-se no seu próprio universo, evitando qualquer fratura e contradição da subjetividade expressa. 
Theodor Adorno encaminha seu discurso para uma análise histórica e não metafísica. Em "Palestra sobre lírica e sociedade”, o pensador da Escola de Frankfurt desestabiliza o idealismo hegeliano quando coloca a sociedade como "unidade em si mesma contraditória". A lírica exige um "protesto contra um estado social que todo indivíduo experimenta como hostil, alheio, frio, opressivo" (ADORNO, 2003, p. 69), o "espírito lírico" reage ao processo de "coisificação do mundo" que se desenvolve sorrateiramente desde a revolução industrial, adestrando e dominando a vida de todos.

Essa abordagem histórica possibilita-nos enxergar a subjetividade lírica como um reflexo direto das contradições e opressões promovidas pelo capitalismo industrial que expurgou a concepção de "liberdade artística" e de "totalidade subjetiva", contrariando qualquer olhar idealista para a materialidade do poema. Adorno enxerga a poesia lírica como um artefato de resistência à mercantilização dos homens e, assim, o sujeito lírico também está imerso nas ambivalências produzidas socialmente, ele é a síntese de um desconforto consolidado pelo plano social decadente e sem esperanças. A unidade tão rogada pelos idealistas não atende mais à necessidade de um mundo repleto de incertezas, onde qualquer experimentação estética e artística resume uma luta para não se degenerar em coisa ou produto do interesse capitalista. Torna-se inviável acreditar em uma "liberdade" e "totalidade" expressivas que de alguma forma não estejam corrompidas pelas estratégias da sociedade do capital.

A problematização da subjetividade lírica realizada por Adorno não elimina a possibilidade de se tomar o objeto como mera confirmação de teses sociológicas. A fuga deste caminho ocorre "quando sua referência ao social revela nelas próprias [as composições líricas] algo de essencial, algo do fundamento de sua qualidade" (ADORNO, 2003, p. 66). O poema não é, segundo o pensador alemão, "mera expressão de emoções e experiências pessoais", elas só são legitimadas na medida em que ganham formas estéticas, conquistando, assim, "sua participação no universal".

Por mais que a questão social e de vida do poeta Glauco Mattoso esteja nitidamente articulada em seus versos, não podemos esquecer que a 
matéria recordada e memorada é deslocada conforme o projeto literário do autor. O uso dado por ele à memória lírica ${ }^{9}$ atesta o perfil contemporâneo dos autores, já que a alcunha de contemporâneo destaca "aquele que mantém fixo o olhar no seu tempo, para nele perceber não as luzes, mas o escuro" (AGAMBEN, 2010, p. 62). Os poetas recordam suas singularidades e particularidades excludentes e "escuras", afrontando e debochando do sistema social e cultural construído pelo império do gosto burguês.

A postura de Glauco Mattoso em acionar "situações de inferiorização" coloca-nos, portanto, em uma lírica com alto "teor social” e essa característica permite observarmos não somente uma individualidade ou particularidade, ela se integra a uma totalidade ou unidade contraditoriamente forjada a partir do sujeito que se edifica na/pela linguagem. A poética de Mattoso "serve de metáfora" para procedermos a uma reflexão sobre o poder de resistência da literatura, uma vez que a incidência de um discurso de si remonta aos desdobramentos e às contradições que assombram a lírica e, consequentemente, a crítica moderna e pós-moderna, porquanto o tom crítico dado às obras que se desenrola desde o século XVII enfatiza o caráter duplo e lacunar existente entre o que é particular e o que seja universal, ou seja, as barreiras entre o subjetivo e o social não são tão nítidas.

As pontuações sobre os aspectos sociais das obras literárias parecem encontrar força no poema “Formal”, de Glauco Mattoso (2004, p. 45):

\section{SONETO 955 FORMAL}

Discute-se qual gênero é mais puro

- haicai, soneto, glosa, oitava ou trova e cada defensor mostra uma prova que num o verso é solto e noutro, duro.

Uns acham que este aqui tem mais apuro, enquanto aquele traz algo que inova; alguns mais radicais chamam de "cova",

\footnotetext{
9 Esta expressão é empregada por Paulo Henriques Brito (2000) no artigo "Poesia e memória", no qual, fazendo uma leitura de ratificação dos valores hegelianos e da soberania da individualidade, o autor corrobora a argumentação sobre a importância da memória para as produções líricas.
} 


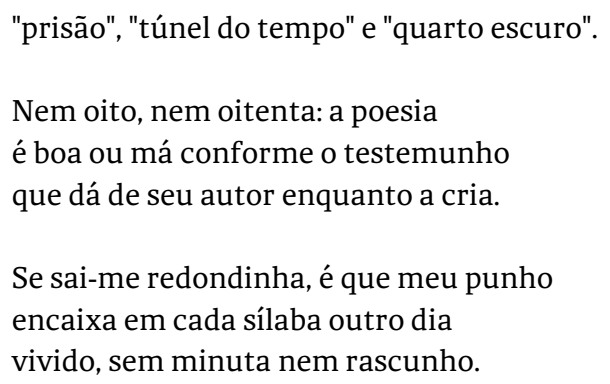

De imediato, o poeta escolhe o soneto para registrar o diálogo que tece com as formulações da crítica literária. Segundo Glauco Mattoso (2014, p. 243):

o soneto é uma forma imexível, uma forma consolidada, cristalizada, mas você não precisa mexer na forma. Você pode até brincar um pouco com a estrutura da forma, mas sem alterá-la; sem alterar os quatorze versos, o verso decassílabo, ou redondilha e etc. Agora, dentro dessa forma você tem infinitas possibilidades de mexer na temática, no discurso, na lógica. E é o que eu faço. O soneto que eu faço é muito diferente do soneto clássico nesse sentido, embora mantenha a estrutura.

A fala do poeta está impregnada de concepções formais do soneto, mas esta estrutura composicional, já consolidada pela práxis dos poetas em todo o ocidente e pela historiografia literária, recebe um tratamento diferenciado por Mattoso, ao aquecê-lo com discursos e temas que fogem à abordagem dada pela maioria dos poetas que registraram seus exercícios líricos nessa forma poética. O poeta não abandona a forma tradicional, mas a nutre com uma matéria testemunhal enriquecida pelos combates travados com a barbárie e a desumanidade que persistem rotineiramente em sua vida.

Os dramas pessoais se camuflam ou se edificam na tessitura poética do autor, destacando uma singularidade que se ancora nas angústias que o ser humano tem e, desse modo, a literatura se aproxima do leitor, criando um elo indissociável com o outro que lhe é comum e estranho. Dessa maneira, o soneto, mesmo em sua rigidez formal ou de conteúdo, será usado de outro modo, ganhando novos contornos a partir dos temas que deslocarão o sentido tradicional atribuído a essa forma; o caráter argumentativo do soneto dá 
"infinitas possibilidades de mexer na temática, no discurso, na lógica", e isto atribui ao processo criativo uma "liberdade" composicional mediada por um poeta que conhece os tratados de versificação poética e, dialeticamente, procura empreender novos usos para esta forma literária. Fica evidente a postura dessacralizadora que Glauco Mattoso pratica; a tradição literária não é abandonada, mas sofrerá questionamentos em um jogo declarado contra a rigidez e as normas que conduzem o sistema literário e a vida de todos. O poeta em questão é um leitor da tradição e não a encara com repúdio, pelo contrário, busca, num território elitista e conservador, espaço para suas angústias e aflições.

No poema "Formal", logo no primeiro verso, a indeterminação do sujeito referente à forma verbal "discute-se" já atesta o caráter irônico e provocador do poeta. O assunto é "qual gênero é mais puro" e, no decorrer da primeira estrofe, são enumeradas seis formas líricas de composição, indo de uma forma mais espontânea ("haicai”), passando pelo "soneto" (de caráter argumentativo) até chegar a formas mais populares ("glosa" e "trova"), valendo-se dessas enumerações para proceder a uma crítica que se desenvolve a partir do axioma do "grau de pureza" que cada uma das estruturas pode revelar. Como se a poesia mais pura estivesse condicionada meramente à forma e não ao conteúdo nela inscrito.

Os rodeios e os circunlóquios produzidos pela crítica literária, que busca provar o que cada forma guarda em sua essência composicional, provoca uma contradição inerente às formulações acerca do propósito primeiro do fazer artístico: manifestar o humano, subordinando o que se deseja expressar à forma, e não o contrário. O gênero mais "puro" está condicionado a um posicionamento mais "duro" ou "solto" daquele que o manuseia. Assim, neste poema, um sujeito lírico, de maneira paradoxal, usa do soneto para argumentar sobre o valor doutrinário da crítica, a qual se atenta mais para o caráter estético do que ético da obra literária, produzindo um saber que amarra o discurso à forma e, nesse sentido, incita uma orientação hierárquica de como se proceder e valorizar o artefato artístico.

A visão do poeta alinha-se à concepção que ele próprio caracteriza como desbunde. Em O que é poesia marginal (1981), Mattoso faz uma análise das produções literárias da década de 1970 e argumenta sobre o fato de elas 
não resultarem de um trabalho "coletivo ou grupal orientado e posicionado contra ou a favor de determinados conceitos" (MATTOSO, 1981, p. 29), desenvolvendo uma argumentação apoiada na "desorganização", "desorientação" e "desinformação" como "traços comuns à maioria dos autores da época”. Estas características grifam a pluralidade de motivos e justificativas que desestabilizam por completo a tentativa de uniformizar o fenômeno artístico deste período, seja pelo rompimento com as editoras de prestígio, seja pela consequente divulgação das obras em forma de panfletos. Assim:

O fato é que a poesia do desbunde não se prende a diretrizes estéticas nem políticas, e esse descompromisso resulta num tratamento irreverente, irônico, de todos os temas, indistintamente, fato que também reflete uma visão crítica da sociedade (e portanto uma atitude política), porém com bom humor (MATTOSO, 1981, p. 46).

No segundo quarteto de "Formal", o teor radical atribuído à forma literária, “cova”, "prisão”, “túnel do tempo" e "quarto escuro", direciona-nos às metáforas que vários poetas utilizaram para se referirem à forma: Bocage (2018), em "Soneto ditado na agonia"10, vê no soneto uma "cova" que lhe conduzirá à eternidade; Carlos Drummond de Andrade (2007), no poema "Quarto escuro"”l, sugere que o sujeito lírico está condenado pelos antigos a esta forma. Esses exemplos são utilizados para destacar o diálogo que o poeta Glauco Mattoso tece com a tradição, ao mesmo tempo em que não se limita a estabelecer um único destino às expressões humanas, embora estas exijam

\footnotetext{
10 “Já Bocage não sou!... À cova escura/ Meu estro vai parar desfeito em vento.../ Eu aos Céus ultrajei! O meu tormento/ Leve me torne sempre a terra dura;// Conheço agora já quão vã figura, / Em prosa e verso fez meu louco intento:/ Musa!... Tivera algum merecimento/ Se um raio da razão seguisse pura.// Eu me arrependo; a língua quasi fria/ Brade em alto pregão à mocidade, / Que atrás do som fantástico corria:// Outro Aretino fui... a santidade/ Manchei!... Oh! Se me creste, gente ímpia, / Rasga meus versos, crê na eternidade!". (BOCAGE, 2018).

11 "Por que este nome, ao sol? Tudo escurece/ de súbito na casa. Estou sem olhos./ Aqui decerto guardam-se guardados/ sem forma, sem sentido. É quarto feito/ pensadamente para me intrigar./ O que nele se põe assume outra matéria/ e nunca mais regressa ao que era antes./ Eu mesmo, se transponho/ o umbral enigmático, / fico a ser, de mim desconhecido./ Sou coisa inanimada, bicho preso/ em jaula de esquecer, que se afastou/ de movimento e fome. Esta pesada/ cobertura de sombra nega o tato, / o olfato, o ouvido. Exalo-me. Enoiteço./ O quarto escuro em mim habita. Sou/ o quarto escuro. Sem lucarna./ Sem óculo. Os antigos/condenam-me a esta forma de castigo." (ANDRADE, 2007, p. 931- 932).
} 
formas para terem o estatuto de universalidade. Nesse sentido, há uma relação paradoxal no trabalho poético de Glauco Mattoso, tanto pelas escolhas das formas quanto pelo resgate intertextual que empreende com outros escritores consagrados pela tradição.

A "qualidade" do conteúdo, segundo o eu lírico de Glauco Mattoso, só pode ser aferida através do "testemunho" que a poesia "dá de seu autor enquanto a cria" e, assim, a poesia e a vida entrelaçam-se, formando uma unidade de impossível desmembramento e, por outro lado, imersa no universo narcísico onde as areias da memória serão remanejadas conforme as necessidades do criador. Toda cri(ação), de alguma maneira, implica uma ação orientada no processo de realização artística e, assim, há um grau de artificialidade e encenação no deslocamento feito pelo artista das memórias recordadas e, posteriormente, ressignificadas no poema. O valor testemunhal do poema não implica uma verdade absoluta sobre o sujeito, mas nos direciona a pensar que este recurso é uma estratégia artística em que a ausência de limites entre sujeito lírico e empírico seja a "chave mestra" do projeto coprofágico de Glauco Mattoso.

O último terceto cria uma atmosfera de entrecruzamento de três instâncias que orbitam o processo de criação: o corpo ("punho"), a escrita ("sílaba") e a experiência ("vivido"). O sujeito lírico apresenta-nos uma concepção de poesia de negociação, "sem minuta", "nem rascunho", como se o vivido tivesse o tamanho e o som de cada palavra recolhida nos versos engendrados. A existência do sujeito lírico de Glauco Mattoso se dá via palavra rememorada e marcada pela condição humana do poeta. Se associarmos a rima testemunho, punho, rascunho à concepção de poesia construída no poema, temos a imagem de um ofício que se realizará a partir do que é experimentado, sendo, portanto, atravessado pelo individual. Vale destacar, neste momento, que o íntimo de alguma maneira é atingido pelo social e, no caso do poeta analisado, sua particularidade "implica o protesto contra uma situação que todo indivíduo experimenta como hostil, alienada, fria e opressiva" (ADORNO, 2003, p. 69).

A menção intertextual a Bocage, anteriormente mencionada, pode ser ratificada pelo poema "Convicto", de Glauco Mattoso, no qual, revisitando o soneto de Bocage, "Soneto ditado na agonia", o poeta reflete sobre o lugar da 
sua poesia na tradição, levando-nos a pensar sobre a necessária relação entre obra, público e reconhecimento:

SONETO 235 CONVICTO

Não pensem que pretendo renegar aquilo que em soneto tenho escrito. Posar de arrependido, de contrito, é ponto a que jamais quero chegar.

Bocage e Kafka ocupam seu lugar ainda que "Me rasguem!" tenham dito. O meu lugar, minúsculo, restrito, ficou inda menor após cegar.

Portanto, palmo a palmo, é meu terreno, do qual não abro mão nem na agonia, malgrado todo o torpe e todo o obsceno.

Palmilham-no outros pés, minha mania. No verso pode ter metro pequeno. Na língua, não se esgota nem se expia. (MATTOSO, 2018). ${ }^{12}$

Neste poema da "fase cega"13 do poeta, notamos a consciência de que o espaço no cânone literário para sua literatura é "minúsculo". Mesmo aludindo a dois escritores já consagrados pela crítica, Bocage e Kafka, nos quais observamos também a ironia e a crítica em relação à sociedade burguesa, Glauco Mattoso vê seu lugar desprestigiado ainda mais depois de sua condição de cego. Tal constatação nos faz refletir sobre quais seriam as implicações para este desabafo. As obras do poeta encontram pouco espaço devido aos temas que abordam: a podolatria, a cegueira, a homossexualidade e o sadomasoquismo. Quem se interessaria pelas obras do poeta em torno de

\footnotetext{
${ }^{12}$ As referências bibliográficas dos poemas e da fortuna crítica utilizadas nesta reflexão foram extraídas do sítio pessoal dos poeta analisado e, muitas vezes, as informações veiculadas não são completas.

${ }^{13}$ A crítica literária costuma dividir a obra de Glauco Mattoso em duas fases, a "visual" e a "cega", sendo esta caracterizada pelas produções artísticas realizadas após a cegueira total do poeta. É oportuno destacar que, nesta fase, ocorre a dominância do soneto como forma de composição literária, como bem pontuado por Winnie Wouters Fernandes Monteiro (2012) no artigo "Os sonetos na obra de Glauco Mattoso".
} 
tais temas? As líricas obscenas e satíricas de Bocage e as prosas de Kafka, que tratam das maneiras como os sujeitos se relacionam com a alienação e a desumanização, encarregam-se, cada uma a sua maneira e estilo, de frisar as exigências que o mundo pós-industrial fez ao artista no contexto em que as estratégias para consolidar uma nova forma social dominante tornam-se um imperativo ${ }^{14}$. Esta longa afirmação também pode ser proferida em relação a Glauco Mattoso, como já bem pontuamos. Portanto, cabe-nos somente transformar os questionamentos acima em afirmações, pois os escritores mencionados se assemelham à figura do "poeta maldito"15, por empreenderem uma literatura que decanta toda rejeição e rebeldia frente aos padrões e às normas sociais. Entretanto, Glauco Mattoso, além de sua militância "em função dos avanços da literatura", promove uma "ação afirmativa gay, podólatra e sadomasoquista" (PIETROFORTE, 2017, p. 71) e, talvez, este seja o motivo pelo qual sua poética não encontre um espaço consagrado, como ocorre com Bocage ou Kafka, e esta premissa valorativa do artefato literário é assim sinalizada pelo poeta: "A minha literatura não vai ser nunca tão popular quanto a de Drummond ou Vinícius, por exemplo. Eu não vou ser tão lido quanto eles" (MATTOSO, 2014, p. 244).

O leitor de Glauco Mattoso, além de se deparar com temas profanos em um espaço completamente sacralizado, o da poesia, encontra, também, uma erudição poética, enriquecida pela intertextualidade, pelos trocadilhos, pelos experimentalismos linguísticos, pela heteronímia e por um diálogo constante com a tradição literária. A aparente coloquialidade dos seus textos mascara todo o trabalho estético que seus poemas desenvolvem, exigindo um perfil de leitor diferenciado. O tom coloquial de sua escrita também é uma estratégia marginal, no sentido em que o coloquial não é mero desconhecimento das estruturas da língua materna, mas é, sobretudo, uma postura política de enfrentamento em relação ao distanciamento que a poesia

\footnotetext{
${ }^{14}$ Estas pontuações acerca de Bocage e Kafka foram articuladas, respectivamente, por Eloísa Porto Corrêa (2013) e Bruno Andrade de Sampaio Neto (2017).

${ }^{15}$ Do francês poète maudit, os poetas malditos são aqueles que rejeitam qualquer imposição, recusando vincular-se à ideologia dominante, postura encontrada em escritores como: Paul Verlaine, Charles-Pierre Baudelaire, Arthur Rimbaud, Edgar Allan Poe, Alejandra Pizarnik, Paulo Leminski, Torquato Neto, Ana Cristina César, entre outros.
} 
parnasiana ${ }^{16}$, consagrada pelo público elitista do século XIX e XX e combatida pelos modernistas de 1922, desencadeou a partir de uma limitação e da exclusão do leitor pouco instruído. As características da literatura marginal apontadas pela crítica e pontuadas anteriormente são identificáveis em Glauco Mattoso, mas, ao mesmo tempo, o poeta se distancia delas pelo trabalho estético que desenvolve, enquadrando-se numa acepção de marginalidade artística que vai além das empreendidas pelos poetas contemporâneos a ele, uma vez que o "desleixo" estético não faz parte do projeto literário do autor. E isto se confirma a partir das seguintes palavras de Mattoso:

Minha marginalidade sempre teve essa mescla de erudição desde o início. Isso já foi apontado pelo José Paulo Paes. Jorge Schwartz, da USP, também já tinha dito que eu sou o marginal entre os marginais, um marginal à margem. Segundo ele, eu não faço aquela coisa tão espontânea, tão coloquial quanto os marginais faziam. Eu misturo a isso a erudição. E isso devido a minha formação de bibliotecário e também o meu autodidatismo, que precedeu a escolha do curso. Eu tenho uma tendência ao enciclopedismo. Aquela mania de "verbetar" tudo, fazer uma coisa sobre cada assunto, de tentar cobrir todos os campos do conhecimento. Isso é uma mania de quem estudou filosofia também, pois as pessoas que estudam filosofia ficam com essa mania metodológica de tentar classificar o conhecimento, catalogá-lo e enquadrá-lo em categorias. E eu sempre fiz isso. De uma forma meio brincalhona, mas sempre fiz. E acho que um pouco da minha preocupação "biblioteconômica" acabou passando para a literatura que eu faço. Eu acho que isso é uma atitude de defesa também, porque sendo deficiente eu preciso me proteger em cima do que eu já li, me resguardar na minha bagagem (2014, p. 244).

\footnotetext{
${ }^{16}$ As seguintes palavras de lumna Simon e Vinícius Dantas (1985) ratificam nossas colocações: "Esta corrente apregoava padrões de contenção e impassibilidade que atendiam a veleidades de esteticismo franco-grego-latino de nossas elites. Encarnou desse modo um conceito de Belas Letras perfeitamente adequado às pretensões de elegância e superioridade de uma burguesia meio austera meio mundana" (SIMON; DANTAS, 1985, p. 48).
} 
Obviamente que, nesses dizeres, já se observa o olhar de um poetacrítico $^{17}$ com visão revolucionária, na medida em que a formação intelectual e a compulsão pelo conhecimento criam um estágio paradoxal de formulação poética, pois um leitor desavisado e desatento depara-se com poemas marcados pela coloquialidade e por uma linguagem mais acessível a qualquer público. No entanto, este recurso estilístico de influência modernista e reincidente na literatura "marginal" se verga a uma estratégia política de resistência que opera sob as contradições do projeto coprofágico de Glauco Mattoso, o qual se desenvolve mediante o uso consciente da tradição, aliando conhecimento e senso crítico acerca do que já se encontra estabilizado pelo cânone literário brasileiro. Nesse sentido, a condução discursiva e temática dos textos do poeta acaba por desestabilizar ainda mais os discursos ultraconservadores da crítica, segundo a qual:

a literatura não teria cor, nem sexo, buscando desqualificar os discursos alheios, chamando "muletas para a poesia" - e outras ofensas que tendem à estupidez - às literaturas afirmativas. Tudo se passa como se o cânone não fosse feito por homens brancos, heterossexuais, católicos, capazes de valorizar o que não fere a tradição, a família e a propriedade privada (PIETROFORTE, 2017, p. 75).

Portanto, acreditar que o cânone literário não resulte dos dispositivos articuladores e hegemônicos para a estabilização e naturalização de uma ética e estética burguesa e capitalista, que exclui modos de ser, agir e criar distintos dos valores socioculturais forjados pela meta homogeneizadora e consolidadora da classe dominante, é, no mínimo, ingenuidade, já que o estranho e desnaturalizado encaminha o artístico para um enfrentamento e confronto com o sistema literário e, consequentemente, político das

\footnotetext{
17 "Seduzidos pelas construções da razão crítica, muitos poetas modernos converteram a poesia em espaço de reflexão crítica e de debate sobre si mesma, propondo-se também a suplementar o trabalho criativo através de textos teóricos sobre questões pertinentes ao fazer literário, ensaios sobre outros autores e outras obras que lhes são afins, bem como reflexões mais generalizadas sobre a poesia e a cultura do seu tempo e do passado. Pode-se dizer que essa prática, fundada na aliança explícita entre criação e reflexão, marcou pelo menos a metade da história da poesia moderna ocidental e ainda vigora, com outros matizes, no cenário crítico contemporâneo [...]" (MACIEL, 1994, p. 76).
} 
estruturas sociais e culturais. A poética de Glauco Mattoso transgride as regras e, nesse sentido, o exercício do poeta se dá através das tensões que ele proporciona ao desenvolver, em formas literárias tradicionais, temáticas que não fazem parte do gosto burguês, uma vez que elas serão ocupadas por conteúdos de si, e estes rompem com o olhar conservador que a crítica direciona ao fazer lírico, o qual está impregnado por juízos que, muitas vezes, se consolidaram sob a crença em uma totalidade lírica de cunho hegeliana. Nesse aspecto, os poemas de Glauco Mattoso constroem uma poética do excesso, pois a harmonia clássica da versificação e do ritmo será arquitetada com vocábulos coloquiais e, muitas vezes, provenientes do universo fetichista do poeta. A tensão promovida entre o que a tradição estética normaliza e o profano da vida é o que dá aos poemas de Glauco Mattoso uma tônica "arrogante". O poeta é um conhecedor das técnicas e engenhos clássicos e assume, com confiança excessiva em si, uma posição lírica debochada e irônica para afrontar e deslocar o sistema literário tradicional.

\section{Referências}

ADORNO, Theodor W. Palestra sobre lírica e sociedade. In: Notas de Literatura I. Trad. Jorge M. B. De Almeida. São Paulo: Duas Cidades: Ed. 34, 2003, p. 65-89.

ANDRADE, Carlos Drummond. Quarto escuro. In: Poesia completa: conforme as disposições do autor. 1a ed. Rio de Janeiro: Nova Fronteira, 2007, p. 931-932.

AGAMBEN, Giorgio. O que é o contemporâneo e outros textos. Chapecó, SC: Argos 2010.

BOCAGE, Manuel Maria de Barbosa l'Hedois du. Soneto ditado na agonia. Disponível em: www.lusopoemas.net/modules/news/article.php?storyid=212657, acesso em: 21/05/2018.

BRITTO, Paulo Henriques. Poesia e memória. In: PEDROSA, Célia. Mais poesia hoje. Rio de Janeiro: 7Letras, 2000, p. 124-131.

BUTHER, Judith. Problemas de gênero. Feminismo e subversão da identidade. Trad. Renato Aguiar - 4a ed. - Rio de Janeiro: Civilização Brasileira, 2012. 
CAMPOS, Augusto; PIGNATARI, Décio; CAMPOS, Haroldo. Teoria da poesia concreta: textos críticos e manifestos 1950-1960. 4. ed. Cotia, SP: Ateliê Editorial, 2006.

CORRÊA, Eloísa Porto. Uma revolução chamada Bocage: inadaptação e libertação. In: Caligrama, Belo Horizonte, v. 18, n. 1, 2013, p. 75-96.

FERREIRA, Glauco B. QWOCMAP: (Auto) Representações de mulheres queer e "de cor" e sua produção audiovisual nos EUA. In: Revista Artemis, Edição V. 14, ago-dez, 2012, p. 68-86, disponível em: http://periodicos.ufpb.br/index.php/artemis/article/viewFile/14288/8166, acessado em 17/06/2018.

HOLLANDA, Heloisa Buarque de. Prefácio. In: HOLLANDA, Heloisa Buarque de (Org.). 26 poetas hoje. 2. ed. Rio de Janeiro: Aeroplano Editora, 1998, p. 9-14.

HOLLANDA, Heloisa Buarque de. Impressões de viagem: CPC, vanguarda e desbunde, 1960-1970. 5. ed. Rio de Janeiro: Aeroplano, 2004.

HOLLANDA, Heloisa Buarque de. A poesia marginal. Disponível em: https://www.heloisabuarquedehollanda.com.br/a-poesia-marginal/. Acesso em: 13 maio 2018.

MACIEL, Maria Esther. Poéticas da lucidez. Notas sobre os poetas-críticos da modernidade. In: Revista de Estudos de Literatura, Belo Horizonte, v. 2, p. 7596, out. 1994.

MATTOSO, Glauco. O que é poesia marginal. São Paulo: Ed. Brasiliense, 1981.

MATTOSO, Glauco. Aos 60 anos, o poeta Glauco Mattoso faz revisão irônica de sua obra. [23/07/2011]. Entrevista concedida a Guilherme Freitas. São Paulo: $O$ Globo. Prosa. Disponível em: https://blogs.oglobo.globo.com/prosa/post/aos60-anos-poeta-glauco-mattoso-faz-revisao-ironica-de-sua-obra-393913.html . Acesso em: 23 mar. 2018.

MATTOSO, Glauco. Poesia Digesta. São Paulo: Landy, 2004.

MATTOSO, Glauco. Soneto 235 convicto. Disponível em: http://www.elsonfroes.com.br/sonetario/psicografado.htm. Acesso em: 25 maio 2018.

MATTOSO, Glauco. Conversando com Glauco Mattoso - O processo criativo do escritor maldito. Entrevista concedida a Ana Paula Aparecida Caixeta e Rosimara Richard. Uniletras, Ponta Grossa, v. 36, n. 2, p. 235-248, jul/dez. 2014. Disponível em: http://www.revistas2.uepg.br/index.php/uniletras. 
MONTEIRO, Winnie Wouters Fernandes. Os sonetos na obra de Glauco Mattoso. In: Revista Estação Literária, Londrina, Volume 9, p. 37-53, jun. 2012, disponível em: http://www.uel.br/pos/letras/EL.

NETO, Bruno Andrade de Sampaio. Ideologia e absurdo na obra de Kafka. 2017. Tese (Pós-Graduação em Ciências Sociais) - Departamento de Ciências Sociais, Universidade Federal da Bahia, Salvador.

OLIVEIRA, Rejane Pivetta de. Literatura marginal: questionamentos à teoria literária. In: Ipotesi, Juiz de Fora, v. 15, n.2- Especial, p. 31- 39, jul/dez, 2011.

PEDROSA, Celia. Poesia e crítica de poesia hoje: heterogeneidade, crise, expansão. In: Estudos Avançados 29, 2015, p. 321 - 333.

PEDROSA, Celia. Poesia, comtemporaneidade e endereçamento. In: Matraga, v.17, n.27, jul./dez. 2010, p. 168- 171.

PIETROFORTE, Antonio Vicente Seraphim. Conhecer Glauco Mattoso. In: Texto Poético, v. 13, n.22, p. 70-96, jan/jun. 2017.

POMBO, Mariana Ferreira. Desconstruindo e subvertendo o binarismo sexual e de gênero: apostas feministas e queer. In: Periódicus, Salvador, n.7, v.1, maioout. 2017, p. 388-404.

SILVA, Susana Souto. O caleidoscópio Glauco Mattoso. Tese (doutorado em Letras e Linguística: Estudos Literários) - Universidade Federal de Alagoas. Faculdade de Letras. Programa de Pós-Graduação em Letras e Linguística. Maceió, 2008.

SIMON, Iumna Maria; DANTAS, Vinícius. Poesia ruim, sociedade pior. Novos Estudos. no 12, 1985, p. 48-61.

WITTIG, Monique. El pensamento heterossexual y otros ensayos. Trad. Javier Sáez y Paco Vidartes. Barcelona: Editorial Egales, 2006.

Recebido em 20 de julho de 2020.

Aceito em 30 de outubro de 2020. 